\title{
The Influence of Financial Performance and Non Financial Performance on Islamic Social Responsibility Disclosure: Evidence from Islamic Banks in Indonesia
}

\author{
Indra Siswanti \\ Departement of Management Perbanas Institute
}

\begin{abstract}
Purpose of this study is to analyze the factors that influence disclosure of Islamic social reporting on Islamic banks. The sample used is 5 banks. The data used in this study are secondary data, consist of annual report Islamic banking period 2010 - 2017. Analysis technique used in this study is panel data regression. The results of fixed effect model state that duties and responsibilities of sharia supervisory board, compliance sharia principles have effect on disclosure of Islamic Social Reporting, while financial performance does not effect on disclosure of Islamic Social Reporting.

Keywords: Social Islamic Reporting, Financial Performance, Duties and Responsibilities of Sharia Supervisory Board, and Compliance Sharia Principles.
\end{abstract}

\section{INTRODUCTION}

The Word Business Council for Sustainable Development (WBCSD, 2009) defines Corporate Social Responsibility, as: "Continuing commitment to business to behave effectively and contributing to economic development while improving the quality of life of the workforce and their families. Well as a company commitment to not only strive to gain profits from the wheel of its business, but also maintain harmony with the social environment around the place of business, through efforts that lead to improving community life in all aspects (Khoirudin, 2013). The practice and disclosure of corporate social responsibility in Indonesia has the support of the government. This is in accordance with the issuance of Law No. 40 of 2007 regarding annual reports must contain some information, one of which is a report on the implementation of social responsibility and environmental.

The concept of corporate social responsibility not only used in conventional economics but also evolves into Islamic economy. In context of Islam and corporate social responsibility, Aribi and Gao (2010) highlight that many existing Islamic business values are essentially consequences of corporate social responsibility activities. Farook (2007) and Basah and Yusuf (2013) state that the 
core basis of corporate social responsibility is from Islamic perspective derives itself from principles, as revealed in the Qur'an. The three major fundamental principles include the vicegerent role of humankind on earth (as a khalifah), divine accountability, and the obligation to encourage good and forbid evil. The concept of corporate social responsibility in Islam is closely related to companies that run their business in sharia and can do out social responsibility towards the surrounding environment.

Banking industries, disclosure of information is very important, especially regarding social, economic and political power activities that have been channelled by individuals and groups in a society, through human, financial and non-financial resources. Because clarity and openness of information from the company are used as material for consideration in decision making. Thus, the scope and objectives of the corporate responsibility report can provide relevant and reliable information that will enable the company to make sociol-economic assessments. One dimension of company reporting that is important for decision making is reporting corporate responsibility (Othman, 2009).

Islamic Social Reporting is a standard reporting social performance for shariabased companies. This index was developed on basis of reporting standard based on the Accounting and Auditing Organization for Islamic Financial Institutions (AAOIFI, 2010), which was subsequently developed by many researchers. Haniffa and Muhammad (2007) state that the purpose of Islamic social reporting is as a form of accountability to Allah SWT and society, and increasing transparency of business activities by presenting relevant information by paying attention to the spiritual needs of Muslim investors or sharia compliance in decision making.

Islamic social responsibility can be influenced by several factors, namely, financial performance, implementation of the duties and responsibilities of the sharia supervisory board, and compliance with sharia principles. Financial performance is a description of the company's financial condition in a certain period, both concerning aspects fund collection and fund distribution, which are usually measured by indicators of capital adequacy, liquidity and profitability (Jumingan, 2006).

Company financial performance can be measured by profitability. Profitability has a very important meaning in an effort to maintain its survival in the long time, because profitability shows whether the company has good prospects in the future. Thus each company will always strive to increase its profitability, because while the level of profitability of a company is high, the survival of the company will be secure (Dilling 2009). 
Social responsibility disclosure is influenced by the implementation of the duties and responsibilities of the sharia supervisory board, because the sharia supervisory board has an important role in Islamic banks. If the implementation of the duties and responsibilities of the sharia supervisory board is done well, the disclosure of Islamic social reporting in the annual report will be good (El Hussein, 2018). The results of Azhar and Bukair (2013) and Inuzula, et. Al (2015), show that the duties and responsibilities of the Sharia Supervisory Board influence Islamic social reporting. Based on description above, the objectives of this study can be made as to test and analyse influence financial performance on Islamic social reporting. Influence implementation duties and responsibilities sharia supervisory board on Islamic social reporting and influence compliance sharia principles on Islamic social reporting on Islamic banks in Indonesia.

\section{LITERATURE REVIEW \\ Legitimacy Theory}

Dowling \& Pfeffer (1975) states that legitimacy is a condition or status that exists when the value system of an entity is congruent with the value system of the wider community in which the entity is located. When there is a difference, whether real or potentially arises between the two value systems, there will be a threat to the legitimacy of the entity. In accordance with O'Donovan (2002)'s statement that legitimacy is an idea that an organization can continue to operate successfully, then the organization must act according to the rules that are widely accepted by the community. Deegan (2002) states that legitimacy theory is a theory which states that organizations are continually looking for ways to ensure their operations are within the limits and norms that apply in society. A company will voluntarily report its activities if management considers that this is what the community expects.

\section{Stakeholder Theory}

Stakeholder theory is a theory that explains that companies must be accountable to parties who have an influence on the company, both internal and external to the company (Freeman \& Jhon, 2001). In addition, stakeholder theory also explains that companies are not entities that only operate for the benefit of their owners, but also must provide benefits to stakeholders, such as shareholders, creditors, consumers, suppliers, government, society, analysts and other parties (Ghozali \& 
Anis, 2014). From the explanation above it can be concluded that the company is responsible not only to the owner but must also be responsible to the stakeholders.

Companies must maintain relationships with stakeholders so that their businesses remain stable. One way that can be done by companies is to accommodate the desires and needs of stakeholders, especially stakeholders who have a major influence on the availability of resources needed by the company in carrying out its business activities, such as labor, company products, etc. (Ghozali \& Anis , 2014).

\section{Islamic Social Reporting}

Concept of Corporate Social Responsibility in Islam is very closely related to companies that implement concept of sharia in conducting business activities. The development of social responsibility in Islamic economics can be increase public awareness of sharia entities (Lestari, 2013). Corporate Social Responsibility from Islamic Perspective, human is representative of God, the creator, and as the representative, human must take care of Allah's creations. Islam is not just a religion but more important is a way of life. The Al-Qur'an and Sunnah govern the life of Muslims and their daily activities, including business enterprises.

At now there is no standards in Indonesia to measure the level of social responsibility disclosure in sharia entities. To assess the disclosure of Islamic Social Reporting refers to 6 assessment themes consisting of financial and investment themes, product and service themes, employee themes, social themes, environmental themes, and corporate governance themes. Each theme consists of items that become benchmarks in the content of the research of each of the themes concerned. Islamic social reporting is calculated by the formula:

$$
\text { ISR }=\frac{\text { Number of items disclousure }}{\text { Number of items expected }} \times 100 \%
$$

Source: Haniffa, 2002

\section{Financial performance}

The effectiveness of the company in generating profits by utilizing assets owned can be measured by profitability ratios. The purpose of assessing bank profitability is to analyse or measure the level of business efficiency and profitability achieved by the bank. The ratio used to measure bank profitability is return on assets. Definition of return on assets according to SEOJK No. 
14/SEOJK.03/2017 is a ratio that assesses how much the rate of return of assets owned by the company.

According to Riyadi (2006) return on assets is a profitability ratio that shows ratio earnings (before tax) and total assets. This ratio is used to measure ability of bank management to obtain profit. The greater return on assets of a bank is reflects greater profit achieved by the bank and it shows better position of the bank in the use of assets. In this study financial performance is measured by return on assets. This ratio can be formulated as follows

$$
\text { ROA }=\frac{\text { Earning before tax }}{\text { Total Assets }} \times 100 \%
$$

\section{Duties and Responsibilities of Sharia Supervisory Board}

The Sharia Supervisory Board has an important role in the supervision process in Islamic banks. The duties and responsibilities of Sharia Supervisory Board in this study are measured by rank in the implementation of the Duties and Responsibilities of Sharia Supervisory Board. Ranking Sharia Supervisory Board can be seen in Self-Assessment report on annual report Islamic banking. The duties and responsibilities of sharia supervisory board refer to regulations central bank No 11/33 / PBI / 2009 concerning the implementation of good corporate governance for Islamic banks and sharia business units. According to SEBI No. 12/13 / Dpbs, implementation of duties and responsibilities sharia supervisory board includes: (1). Assessing and ensuring compliance with sharia principles for operating guidelines and products issued by banks, (2). Monitoring process of developing new products in accordance with DSN-MUI fatwa, (3). Requesting a fatwa to DSN-MUI for new products that have not there is a fatwa, (4). Periodically review fulfilment of sharia principles on mechanism of collection and distribution of funds and bank services, (5). Request data and information related to sharia aspects from unit of bank's in order to carry out its duties.

If the value of implementing good corporate governance for indicators of implementation of duties and responsibilities of sharia supervisory board gets a small ranking, so Islamic banks are stated to be able better disclose their reports of social responsibility (Khasanah and Agung, 2015). 


\section{Table 1}

Composite rating duties and responsibilities of sharia supervisory board

\begin{tabular}{ccc}
\hline Rating & Weight & $\begin{array}{c}\text { Value } \\
\text { (Rating x Weight) }\end{array}$ \\
\hline 1 & $10 \%$ & 0,10 \\
2 & $10 \%$ & 0,20 \\
3 & $10 \%$ & 0,30 \\
4 & $10 \%$ & 0,40 \\
5 & $10 \%$ & 0,50 \\
\hline
\end{tabular}

Source: SEBI No.12/13/DpbS

\section{Compliance Sharia Principles}

Sharia compliance is part of good corporate governance in Islamic banking. Sharia compliance is the cultivation of compliance with sharia principles in the implementation of sharia-based company activities (Alsaadi et.al). Disclosure of syaraih compliance is the most relevant component as the provision of information on sharia compliance in a company (Asrori, 2011). Sharia Company is said to have a good value of sharia compliance if the business is in accordance with sharia principles. Sharia compliance in Islamic bank can be reflected implementation of sharia principles in activities of raising funds and channelling funds and services in banking.

Compliance sharia principles in this study is measured by ranking of implementation sharia principles in fund raising activities, fund distribution, and service services. The rating can be seen in the self-assessment report on the annual report of Islamic banks. If the value self-assessment for sharia principles implementation indicators in fund raising activities, fund disbursement and services in obtaining a small value rating, so this indicates that Islamic banks have fulfilled sharia compliance aspects. (Khasanah and Agung, 2015).

\section{Table 2}

Composite rating compliance sharia principles

\begin{tabular}{ccc}
\hline Rating & Weight & $\begin{array}{c}\text { Value } \\
\text { (Rating x Weight) }\end{array}$ \\
\hline 1 & $5 \%$ & 0,05 \\
2 & $5 \%$ & 0,10 \\
3 & $5 \%$ & 0,15 \\
4 & $5 \%$ & 0,20 \\
5 & $5 \%$ & 0,25 \\
\hline
\end{tabular}




\section{Theoretical Framework and Hypothesis.}

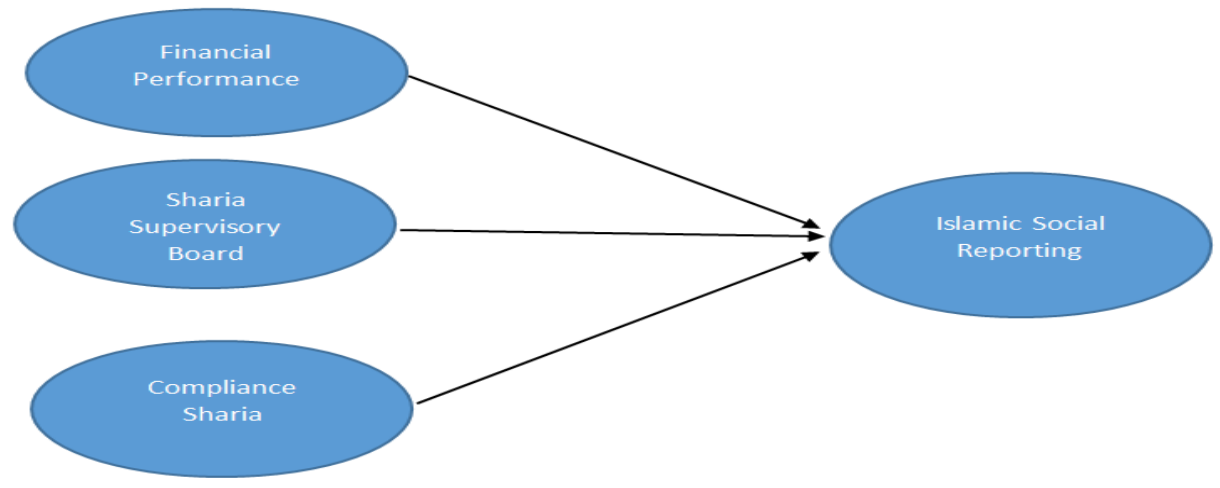

Figure 1. Research Framework

\section{Hypothesis}

\section{Effect financial performance on disclosure of Islamic social reporting}

The financial performance of firm is description of condition financial company which is analysed by financial analysis tools, so that it can be known about good or bad financial condition of a company that reflects performance in a certain period. The financial performance of firm is achievement of company in a certain period so that it reflects level of health of the company (Sutrisno, 2009).

Asset returns can measure a company's ability to generate profits in the past and then projected in the future (Ningrum, et.al 2013). Higher asset returns indicate a better level of bank financial performance. With good financial performance, banks will voluntarily disclose their social responsibilities.

Nawaiseh's research (2015) states that company performance reflected by return on assets shows a significant effect on corporate social responsibility disclosure for employee dimensions. Maskun's research (2013) states that the level of leverage, firm size and profitability have a significant influence on corporate social responsibility disclosure, which in turn can improve people's welfare. Siswanti et. al research (2017) states that financial performance has a significant effect on business continuity of Islamic banks. Based on the theoretical basis and results of research previously, the hypothesis can be proposed as follows:

H1: Financial performance has a significant effect on disclosure of Islamic social reporting disclosure.

Effect duties and responsibilities of sharia supervisory board on disclosure of Islamic social reporting 
Sharia supervisory board has an important role in process of controlling Islamic banks. Sharia supervisory board has the authority to provide input and remind management of Islamic banks in managing Islamic banks and management policies in relation to compliance with sharia principles. Azhar and Bukair (2013) states that duties and responsibilities of sharia supervisory board have a significant effect on the disclosure of Islamic social reporting. Based on theoretical basis and results of previous researchers, hypothesis can be proposed as follows:

$\mathrm{H} 2$ : Implementation duties and responsibilities of shariah supervisory board has a significant effect on disclosure Islamic social reporting.

\section{Effect Compliance Sharia Principles on disclosure of Islamic Social Reporting}

Islamic banks in carrying out their activities must comply with laws and sharia principles. Sharia compliance can be reflected in implementation and activities of raising and channelling funds and services. Sharia enterprise theory explains that Islamic banks as a sharia entity running their business in accordance with sharia principles will carry out the disclosure of Islamic social reporting as a form of trust and accountability to Allah SWT which is the main stakeholder in the company. So that the high level of sharia compliance will be able to influence the extent of Islamic social reporting disclosure (Nissa, 2017). Khasanah and Agung (2015) stated that shariah compliance had a significant effect on disclosure of Islamic social reporting. Based on theory and results of previous researchers, the hypothesis can be proposed as follows:

H3: Compliance sharia principles has a significant effect on disclosure of Islamic social reporting.

\section{RESEARCH METHODOLOGY}

Research Design this is an explanatory study that describes the causal relationship by testing the influence of independent variables on dependent variables through quantitative descriptive analysis. The population used in this study is 13 Islamic Banks in Indonesia. The sample selection was done using a purposive sampling method. The sample used in this study is 5 Islamic commercial banks. The data used are secondary data consist of the annual report, corporate governance report, and financial statements report period 2010-2017. The data in this study are panel data which then data is processed using E-views 10.0.

\section{RESULT}

\section{Method panel data regression}


Panel data regression analysis can be done using three estimation models, namely common effect, fixed effect, and random effect. The following is a description of the estimation results:

Table 3

Common Effect

\begin{tabular}{|c|c|c|c|c|}
\hline Variable & Coofficiont & Std. Error & t-Statistic & Prob. \\
\hline $\begin{array}{c}\text { ROA } \\
\text { TJUDPS } \\
\text { KTPPS } \\
\text { C }\end{array}$ & $\begin{array}{r}0.354791 \\
-103.6887 \\
89.81231 \\
91.49060\end{array}$ & $\begin{array}{l}1.720306 \\
35.77766 \\
47.38318 \\
4.633640\end{array}$ & $\begin{array}{r}0.206237 \\
-2.898140 \\
1.895447 \\
19.74487\end{array}$ & $\begin{array}{l}0.8378 \\
0.0064 \\
0.0661 \\
0.0000\end{array}$ \\
\hline $\begin{array}{l}\text { R-squared } \\
\text { Adjusted R-squared } \\
\text { S.E. of regression } \\
\text { Sum squared resid } \\
\text { Log likelinood } \\
\text { F-statistic } \\
\text { Prob(F-statistic) }\end{array}$ & $\begin{array}{r}0.190651 \\
0.123205 \\
8.879134 \\
2838.205 \\
-141.9985 \\
2.826731 \\
0.052223\end{array}$ & \multicolumn{2}{|c|}{$\begin{array}{l}\text { Mean dependent var } \\
\text { S.D. dependent var } \\
\text { Akaike info criterion } \\
\text { Schwarzoriterion } \\
\text { Hannan-Quinn criter. } \\
\text { Durbin-Watson stat }\end{array}$} & $\begin{array}{l}83.32500 \\
9.482474 \\
7.299925 \\
7.468813 \\
7.360989 \\
0.389368\end{array}$ \\
\hline
\end{tabular}

Source: Data processed (2018)

Table 4

Fixed Effect

\begin{tabular}{|c|c|c|c|c|}
\hline Variablo & Coofficiont & Std. Error & t-Statistic & Prob. \\
\hline $\begin{array}{c}\text { ROA } \\
\text { TJDPS } \\
\text { KTPPS } \\
\text { O }\end{array}$ & $\begin{array}{r}-0.317871 \\
-91.15591 \\
105.3435 \\
88.73498\end{array}$ & $\begin{array}{l}1.615195 \\
35.15388 \\
43.08941 \\
4.040676\end{array}$ & $\begin{array}{r}-0.196800 \\
-2.593054 \\
2.444767 \\
21.96043\end{array}$ & $\begin{array}{l}0.8452 \\
0.0142 \\
0.0202 \\
0.0000\end{array}$ \\
\hline \multicolumn{5}{|c|}{ Effocts Spocification } \\
\hline \multicolumn{5}{|c|}{ Cross-soction fixod (dummy variablos) } \\
\hline $\begin{array}{l}\text { R-squarod } \\
\text { Adjustod R-squarod } \\
\text { S.E. Of rogrossion } \\
\text { Sum squarod rosid } \\
\text { Log likolihood } \\
\text { F-statistic } \\
\text { Prob(F-statistic) }\end{array}$ & $\begin{array}{r}0.535513 \\
0.433906 \\
7.134538 \\
1628.852 \\
-130.8926 \\
5.270454 \\
0.000447\end{array}$ & $\begin{array}{l}\text { Mean depen } \\
\text { S.D. dopond } \\
\text { Akaiko info } \\
\text { Schwarzorit } \\
\text { Hannan-Qui } \\
\text { Durbin-Wats }\end{array}$ & $\begin{array}{l}\text { ntvar } \\
\text { tvar } \\
\text { orion } \\
\text { on } \\
\text { critor. } \\
\text { stat }\end{array}$ & $\begin{array}{l}83.32500 \\
9.482474 \\
6.944628 \\
7.282404 \\
7.066758 \\
0.620215\end{array}$ \\
\hline
\end{tabular}

Source: Data processed (2018)

Table 5

Random Effect

\begin{tabular}{|c|c|c|c|}
\hline Variablo & Coofficiont & Std. Error & Prob. \\
\hline $\begin{array}{l}\text { ROA } \\
\text { THDPS } \\
\text { KTPPS } \\
\text { O }\end{array}$ & $\begin{array}{r}0.354791 \\
-103.6887 \\
89.81231 \\
91.49060\end{array}$ & $\begin{array}{r}0.256608 \\
-3.606817 \\
2.358937 \\
24.57304\end{array}$ & $\begin{array}{l}0.7989 \\
0.0009 \\
0.0239 \\
0.0000\end{array}$ \\
\hline \multicolumn{4}{|c|}{ Efrocts Spocification } \\
\hline $\begin{array}{l}\text { Oross-sootion random } \\
\text { ldiosymoratio random }\end{array}$ & & $\begin{array}{l}0.000000 \\
7.134538\end{array}$ & $\begin{array}{l}0.0000 \\
1.0000\end{array}$ \\
\hline \multicolumn{4}{|c|}{ Woightod Statistios } \\
\hline $\begin{array}{l}\text { R-squarod } \\
\text { Adjustod R-squarod } \\
\text { S.E. orrogrossion } \\
\text { F-stetistid } \\
\text { Prob(F-statistia) }\end{array}$ & $\begin{array}{l}0.190651 \\
0.123205 \\
8.879134 \\
2.826731 \\
0.052223\end{array}$ & $\begin{array}{l}\text { Moan dopondont var } \\
\text { S.D. dopondont ver } \\
\text { Sum squarod rosid } \\
\text { Durbin-Watson stet }\end{array}$ & $\begin{array}{l}83.32500 \\
9.482474 \\
2838.205 \\
0.389368\end{array}$ \\
\hline
\end{tabular}

Source: Data processed (2018)

\section{Selection Panel Data Regression Model}




\section{Chow-test}

Chow test is done to choose a better model, whether using common effects or Fix Effects method. The following are the results obtained from the Chow-test.

\section{Table 6}

Chow-test

\begin{tabular}{lrrr}
\hline \hline Effects Test & Statistic & d.f. & Prob. \\
\hline \hline Cross-section F & 5.939656 & $(4,32)$ & 0.0011 \\
Cross-section Chi-square & 22.211847 & 4 & 0.0002 \\
\hline \hline
\end{tabular}

Source: Data processed (2018)

The Chow Test show that the probability F-test value is 0.0011 and chi-square is $0.0002<0.05$, so it can be concluded that estimation of fixed effects model is better than estimation of common effects model.

\section{Hausman test}

The Hausman test is done to choose a better model, whether using a fixed effect model or a random effect model. The following are results obtained from the Hausman test.

\section{Table 7}

Hausman Test

\begin{tabular}{lrcr}
\hline \hline Test Summary & Chi-Sq. Statistic & Chi-Sq. d.f. & Prob. \\
\hline \hline Cross-section random & 23.737897 & 3 & 0.0000 \\
\hline \hline
\end{tabular}

Source: Data processed (2018)

The Hausman-test shows probability Chi-Square value is $0.0000<0.05$. Thus it can be concluded that fix effect model is better than random effect model.

\section{F-test (Goodness of Fit)}

Goodness of fit is used to test whether the model in study is feasible for continuation or not 


\section{Table 8}

F-test

\begin{tabular}{lrll}
\hline \hline R-squared & 0.535513 & Mean dependent var & 83.32500 \\
Adjusted R-squared & 0.433906 & S.D. dependent var & 9.482474 \\
S.E. of regression & 7.134538 & Akaike info criterion & 6.944628 \\
Sum squared resid & 1628.852 & Schwarz criterion & 7.282404 \\
Log likelihood & -130.8926 & Hannan-Quinn criter. & 7.066758 \\
F-statistic & 5.270454 & Durbin-Watson stat & 0.620215 \\
Prob(F-statistic) & 0.000447 & & \\
\hline
\end{tabular}

Source: Data processed (2018)

Based on table 5 above, the results of the F-statistical probability are 0,000447 $<0.005$. Thus the model in this study is feasible to continue

\section{T-test}

The $t$ test is used to test influence of each independent variable on the dependent variable.

\begin{tabular}{crrrr}
\multicolumn{6}{c}{ Table 9 } \\
T-test & & \\
\hline \hline Variable & Coefficient & Std. Error & t-Statis tic & Prob. \\
\hline \hline ROA & -0.317871 & 1.615195 & -0.196800 & 0.8452 \\
TJJDPS & -91.15591 & 35.15388 & -2.593054 & 0.0142 \\
KTPPS & 105.3435 & 43.08941 & 2.444767 & 0.0202 \\
C & 88.73498 & 4.040676 & 21.96043 & 0.0000 \\
\hline \hline
\end{tabular}

Source: Data processed (2018)

From table 9, we can conclude the effect between variables as follows:

1. The value of probability financial performance variable is $0.8452>0.05$. This shows that financial performance does not affect disclosure of Islamic social reporting.

2. The value of probability duties and responsibilities of shariah supervisory board is $0.0142<0.05$. This shows that the duties and responsibilities of sharia supervisory board has a significant effect on disclosure of Islamic social reporting.

3. The value of probability compliance sharia principles is $0.0202<0.05$. This shows that compliance sharia principles has a significant effect on disclosure of Islamic social reporting 


\section{Determination Coefficient Test (R2)}

The following are results of determinant coefficient test (R2) as follows:

Table 10

Determination Coefficient Test $\left(\mathrm{R}^{2}\right)$

\begin{tabular}{lrll}
\hline \hline & & & \\
R-squared & 0.535513 & Mean dependent var & 83.32500 \\
Adjusted R-squared & 0.433906 & S.D. dependent var & 9.482474 \\
S.E. of regression & 7.134538 & Akaike info criterion & 6.944628 \\
Sum squared resid & 1628.852 & Schwarz criterion & 7.282404 \\
Log likelihood & -130.8926 & Hannan-Quinn criter. & 7.066758 \\
F-statistic & 5.270454 & Durbin-Watson stat & 0.620215 \\
Prob(F-statistic) & 0.000447 & & \\
\hline \hline
\end{tabular}

Source: Data processed (2018)

Based on determination coefficient test $\left(\mathrm{R}^{2}\right)$, shows results of adjusted R-squared is 0.433906 or $43.3906 \%$. This shows that variable financial performance, assignments and responsibilities sharia supervisory board, and compliance with sharia principles can explain variable disclosure of Islamic social reporting of $43.40 \%$. While the remaining $56.60 \%$ is explained by other variables not used in this study.

\section{DISCUSSION}

\section{Effect financial performance on disclosure of Islamic social reporting}

The results showed that financial performance has no affect on disclosure of Islamic social reporting. Because companies that have high profitability values do not necessarily carry out many social activities, and disclose them in annual reports, because companies are more profit oriented. Management is more interested in focusing on disclosing financial information only and considers it unnecessary to report things that can disrupt corporate financial information such as information about corporate social responsibility disclosures.

The companies that have high profitability do not necessarily want to do social activities because the company is more oriented to profit alone. O'Donovan (2000) states that when high profit companies are not required to disclose social responsibility to the company.

Effect duties and responsibilities of sharia supervisory board on disclosure of Islamic social reporting 
Based on results of this study, it was shown that the duties and responsibilities of sharia supervisory board has a significant effect on disclosure Islamic social reporting, because the bank will carry out disclosure of social responsibility well to get trust from the public. With the good disclosure of bank social responsibility to the public, the bank will make efforts to serve interests of the wider community. The existence of good disclosure social responsibility is influenced by the implementation of assignments and responsibilities of the sharia supervisory board, because sharia supervisory board has an important role in Islamic banks. If the implementation of duties and responsibilities of sharia supervisory board has been carried out properly, then the disclosure of Islamic social reporting in the annual report will also be good. This research is in line with research of Azhar and Bukair (2013), Inuzula (2017) which states that duties and responsibilities of sharia supervisory board have a significant effect on disclosure of Islamic social reporting.

\section{Effect compliance sharia principles on disclosure of Islamic social reporting}

The results of this study indicate that duties and responsibilities of sharia supervisory board have a significant effect on disclosure of Islamic social reporting. Because if the value of implementation of sharia principles in fund raising and fund disbursement and service services in Islamic banking fulfils sharia compliance aspects, the bank's ability to disclose Islamic social responsibility reports will be higher. This research is in line with Khasanah and Agung (2015) stating that sharia compliance has a significant effect on disclosure Islamic social reporting.

\section{CONCLUSION AND IMPLICATION}

Based on the results of this study it can be concluded, that financial performance does not affect on disclosure of Islamic social reporting, duties and responsibilities of sharia supervisory board have a significant effect on disclosure of Islamic social reporting and compliance sharia principles have a significantly effect on disclosure of Islamic social reporting. The implications of the results of this study are expected to provide input to Islamic banks in Indonesia to continuously improve their performance, especially financial performance, because financial performance can have an impact on performance of Islamic banks in Indonesia. 


\section{REFERENCES:}

Accounting \& Auditing Organization for Islamic Financial Institution (AAOIFI). (2010). Financial Accounting Standart No.9 (FAS 9): Zakah, Accounting and Auditing Organization for Islamic Financial Institutions. Bahrain.

Alsaadi, Abdullah., Ebrahim, M.S. and Jaafar, A. (2016), Corporate Social Responsibility, Shariah-Compliance, and Earnings Quality. Journal of financial services research. Vol. 51(2), 169-194.

Aribi, Z. A. \& Gao, S. (2010). Corporate Social Responsibility Disclosure: A Comparison between Islamic and Conventional Financial Institutions. Journal of Financial Reporting and Accounting. Vol. 8(2), 72-91.

Asrori. (2011). Pengungkapan Syari'ah Compliance dan Kepatuhan Bank Syariah Terhadap Prinsip Syariah (disclousure compliance of syariah and compliance of Islamic Banks on sharia principles). Jurnal Dinamika Akuntansi. Vol. 3 (1), 1-7.

Basah, M.Y.A, \& M..Md Yusuf. (2013). Islamic Bank and Corporate Social Responsibility (CSR). ESBM-special Issue: Islamic Management and Business. Vol. 5(11), 194-209.

Deegan, Craig. (2002). Introduction: The Legitimising Effect of Social and Environmental Disclosure - A Theoritical Foundation. Accounting, Auditing, and Accountability Journal.Vol.5 (3), 282-311.

Dilling. (2009). Sustainability Reporting In A Global Context: What Are The Characteristics of Corporations That Provide High Quality Sustainability Reports - An Empirical Analysis. International Business \& Economics Research Journal. Vol.9 (1), 19-30.

Dowling, J. and Pfeffer, J. (1975). Organizational Legitimacy: Social Values An Organizational Behaviour. Pacific Sociological Journal Review. Vol.18 (1), 122-136.

El Hussein, Nawal Hussein Abbas (2018). The Sharia Supervisory Board: Does it Influence Corporate Social Responsibility Disclosure by Islamic Banks? A Review. Journal of Islamic Studies and Culture. Vol. 6(1), 121-132.

Farook, Sayd. (2007). On Corporate Social Responsibility of Islamic Financial Institutions. Islamic Economies Studies. Vol.15(1), 31-46.

Freeman, R.Edward dan John Mc Vea. (2001). A Stakeholder Approach to Strategic Management. Darden Business School Working Paper. No. 01- 02. Ghozali, Imam and Anis, Chariri. (2014). Teori Akuntansi (Accounting Theory). Semarang: Badan Penerbit Universitas Diponegoro.

Haniffa, Roszaini., and Muhammad, Hudaib. (2007). Exploring the Ethical Identity if Islamic Bank via Communication in Annual Reports. Journal of Business Ethics. Vol.76, 97-116.

Inuzula, Lakharis. , Basri, Hasan., and Shabri. (2015). Peran Dewan Pengawas Syariah dan Dewan komisaris Dalam Mengungkapkan Islmaic Social 
Reporting Pada Bank Umum Syariah di Indonesia (The Role of Sharia Supervisory Board and Board of Commissioners in Disclousure Islamic Social Reporting Islamic Banks in Indonesia). Jurnal Magister Akuntansi. Vol. 4(4), 68-78.

Jumingan. (2006). Analisis Laporan Keuangan. Jakarta: Bumi Aksara.

Khasanah, Zayyinatul., and Agung, Yulianto. (2015). Islamic Corporate Governance dan Pengungkapan Islamic Social Repoting Pada Bank Umum Syariah (Islamic Corporate Governance and Disclosure of Islamic Social Reporting Islamic Banks in Indonesia). Accounting Analysis Journal. Vol. 4(4), 1-10.

Khoirudin, Amirul. (2013). Corporate Governance dan Pengungkapan Islamic Social Reporting Pada Perbankan Syariah di Indonesia (Corporate Governance and Disclosure Islamic Social Reporting iIslamic Banks in Indonesia). Accounting Analysis Journal. Vol.2 (2), 227-232.

Lestari, Puji. (2013). Determinants of Islamic Social Reporting in Syariah Banks: Case of Indonesia. International Jurnal of Business and Management Invention. Vol. 2(10), 28-34.

Maskun, Ali. (2013). Leverage level, company size, profitability toward the disclosure of Corporate Social Responsibility (CSR) of LQ-45 companies in Indonesia stock xchange. International Journal of Academic Research. Vol. 5(2), 140-144.

Nawaiseh, Mohammad. (2015). Do Firm Size and Financial Performance Affect Corporate Social Responsibility Disclosure: Employees' and Environmental Dimensions? American Journal of Applied Sciences. Vol.12 (12), 967-981.

Ningrum, R.A., and Fachrurrozie PYJ. (2013). Pengaruh Kinerja Keuangan, Kepemilikan Institusional dan Ukuran Dewan Pengawas Syariah Terhadap Pengungkapan Islamic Social Responsibility (Effect of Financial Performance, Institutional Ownership and Size of Sharia Supervisory Board on Disclosure of Islamic Social Responsibility.) Accounting Analysis Journal. Vol. 2(4), 430-438.

O'Donovan, Garry. (2002). Environmental Disclosure in The Annual Report: Extending The Applicability and Predictive Power of Legitimacy Theory. Accounting, Auditing, and accountability Journal. Vol. 15(3), 344-371.

Othman, Rohana. (2009). Determinants of Islamic Social Reporting Among Top Sharia-Approved Companies in Bursa Malaysia. Research Journal of International Studies. Vol. 12, 4-20.

Surat Edaran Otoritas Jasa Keuangan No.14/SEOJK.03/2017 tentang Penilaian Tingkat Kesehatan Bank Umum

Peraturan Bank Indonesia No. 11/33/PBI/2009. Tentang Pelaksanaan Good Corporate Governance Bagi Bank Umum Syariah dan Unit Usaha Syariah. Rahman, Azhar Abdul and Bukair, Abdullah Awadh. (2013), The Influence of the Shariah Supervision Board on Corporate Social Responsibility Disclosure 
by Islamic Banks of Gulf Co-Operation Council Countries. V01. 6(2), 65104.

Riyadi, Selamet (2006). Banking Assets and Liability Management, Edisi Ketiga. Jakarta: Fakultas Ekonomi Universitas Indonesia.

Siswanti, Indra., Ubud Salim., Eko Ganis S., and Siti Aisjah. (2017). Sustainable Business of Islamic Bank Through on the Islamic Corporate Governance and Islamic Financial Performane. Journal Finance \& Banking Review. Vol.2(2), 15-23.

Siswanti, Indra., Ubud Salim., Eko Ganis S., and Siti Aisjah. (2017) The Impact of Islamic Corporate Governance, Islamic Intellectual Capital and Islamic Financial Performance on Sustainable Business Islamic Banks. International Journal Economics and Financial Issues. Vol.7(4), 316-323.

Surat Edaran Bank Indonesia No. 12/12/DPbS/2010-Pelaksanaan Good Corporate Governance bagi Bank Umum Syaria dan Unit Usaha Syariah.

Sutrisno. (2009). Manajemen Keuangan Teori, Konsep dan Aplikasi, Edisi Pertama, Cetakan Ketujuh, Penerbit Ekonisia, Yogyakarta. 